\title{
Dzieło uobecnienia zbawczych tajemnic Chrystusa w ujęciu Wacława Hryniewicza OMI
}

\section{THE ACTUALIZATION OF THE CHRIST'S REDEMPTIVE MYSTERIES ACCORDING TO WAC ŁAW HRYNIEWICZ OMI}

The article is an attempt to systematize the Wacław Hryniewicz's interpretation of the Christ's redemptive mysteries. That is why the article demonstrates the importance of the Holy Spirit thanks to whom the paschal mystery is continued in the Church - the glorious Body of Christ. In that way, people of the all times can participate in the mystery of Christ to unite with Him. The Christ's redemptive mysteries are actualized in a mysterious, but real way by the word of God, faith, sacraments and human activity. The author of the paschal trilogy gives weight to the thought, that there is one, the same and undivided presence of Christ and the Holy Spirit. Thanks to them all the redemptive means, that is preaching, cult, service become the area of spiritual revival and resurrection for the human. The article tries to answer how the Christ's redemptive mysteries are actualized. It emphasize that all redemptive means of the Church overcome and complete each other.

Key words: paschal mystery, actualization of the redemptive mysteries, the word of God, faith, sacraments, human activity.

Lubelski teolog stwierdza, że istnieje wiele sposobów obecności misterium Chrystusa w Kościele (por. KL 7, KO 2). Rozciąga się ona na wszystkie wymiary kościelnego życia. Nie można ich ograniczać tylko 
Teologia dogmatyczna

do czynności sakramentalnych, bowiem uprzywilejowanym miejscem obecności Chrystusa jest także wiara, modlitwa i całe posługiwanie Kościoła. Jednak w paschalnym doświadczeniu Kościoła, stwierdza Hryniewicz, słowo i sakrament zajmują szczególne miejsce. Jako „dwa stoły" pokarmu duchowego stanowią dwie podstawowe rzeczywistości zbawcze Kościoła, które przenikają się wzajemnie i uzupełniają. W nich owa obecność realizuje się najpełniej.

Zdaniem Hryniewicza istnieje jedna, ta sama i niepodzielna obecność Chrystusa. Dlatego twierdzi, że należałoby raczej mówić nie tyle o obecności Chrystusa w Kościele, co o Kościele w kręgu obecności Paschy. Dzięki takiemu ujęciu priorytet należy do obecności Chrystusa i Jego Ducha, przez którą wszystkie środki Zbawienia, przepowiadanie, kult, posługiwanie, stają się miejscem duchowego odrodzenia i zmartwychwstania ${ }^{1}$. Trzeba zatem odpowiedzieć na pytanie, w jaki sposób dokonuje się uobecnienie misterium Chrystusa na płaszczyźnie sakramentalnej oraz egzystencjalnej.

\section{Uobecnienie przez słowo Boże}

Słowo Boże i jego głoszenie jest jednym z podstawowych środków uobecniania zbawczego misterium Chrystusa. Przez Słowo bowiem rodzi się wiara, która z kolei wyraża się i umacnia przez sprawowanie świętych sakramentów. Głoszone dziś, po 2000 lat od Jego objawienia, jest wciąż aktualnym i tym samym słowem, które ongiś wypowiadał Zbawiciel wzywając do wiary i nawrócenia. Według autora trylogii paschalnej przepowiadanie Kościoła posiada zbawczą moc dzięki tej właśnie tożsamości: jest to bowiem słowo Chrystusa i Jego Ducha.

Hryniewicz stwierdza, że całe Pismo Święte nie tylko mówi o Chrystusie, ale ono jest Chrystusem. Za Evdokimovem nazywa Biblię „słowną ikoną Chrystusa", ponieważ cała napełniona jest Jego obecnością². Zdaniem autora, głębokie utożsamienie słowa z Chrystusem-Logosem najgłębiej wyraża prolog Ewangelii Janowej, który głosi, że Słowo stało się Człowiekiem i słowem Boga do ludzi. Całe ziemskie życie Jezusa

1 Por. W. Hryniewicz, Nasza Pascha z Chrystusem. Zarys chrześcijańskiej teologii paschalnej, t. 2, Lublin 1987, s. 182, dalej: Pascha II.

2 Por. Pascha II, s. 185. Gdy teologowie mówią o Piśmie Świętym jako ikonie Chrystusa, dalecy są od rozumienia tej obecności na wzór unii hipostatycznej. W odróżnieniu od pojmowania tekstu biblijnego jako „okna”, przez które można zobaczyć dawną historię, model ikony wskazuje na obecność eschatologicznej rzeczywistości niejako „przed” tekstem, tj. w świecie, który Pismo wtórnie projektuje w zetknięciu z czytelnikiem. Nie chodzi zatem o rozumienie fundamentalistyczne, ale symboliczne. Por. R. Bieringer, The Authority of the Bible for Theology, „Bulletin ET. Zeitschrift für Theologie in Europa“ 8(1997), s. 52-67. 
naznaczone było głoszeniem słowa o Bogu i jednocześnie uobecniało Boga pośród ludzi. Głosząc Królestwo Boże, Chrystus czynił je rzeczywistością bliską i dostępną dla słuchaczy. Kulminacyjnym wydarzeniem i potwierdzeniem treści przepowiadania było misterium Paschy, które dopełniło obecność Boga w Jezusie ukrzyżowanym i zmartwychwstałym. Stało się równocześnie punktem zwrotnym w zbawczym przepowiadaniu, ponieważ ,przeżycie misterium Paschy przez uczniów stało się równocześnie przejściem od Ewangelii Jezusa do Ewangelii o Jezusie Chrystusie. W rzeczy samej chodzi o jedną i tę samą Ewangelię, która daje świadectwo o obecności Boga w całej egzystencji Jezusa Chrystusa. Zbawienie już się dokonało i jest w Nim obecne"3. Dlatego głoszenie Ewangelii, stwierdza Hryniewicz, jest tożsame z przepowiadaniem śmierci i Zmartwychwstania Chrystusa. Stąd właśnie czerpie zbawczą moc, która sprawia, że słowo jest nie tylko wspomnieniem minionych wydarzeń, ale uobecnieniem tego, o czym mówi, jest „tajemniczą epifanią zbawienia”4.

Staje się to bardziej wyraźne, gdy Hryniewicz tłumaczy uobecnienie Chrystusa odwołując się do obietnicy złożonej przez Zmartwychwstałego. Powołując Kościół jako kontynuację swego zbawczego dzieła, składa On uczniom obietnicę, że będzie obecny w przepowiadaniu wspólnoty wierzących (zob. Mt 28, 18-20; J 20, 23). Ta kontynuacja jest nieodłączna, wręcz uwarunkowana posłaniem Parakleta. To właśnie Duch sprawia, że głoszone przez Jezusa słowo nie jest martwą literą, jest wciąż aktualne w słowie ludzkim i pozostaje żywym słowem samego Chrystusa. Hryniewicz stwierdza wyraźnie, że w przytaczanej przez Jana mowie pożegnalnej, kontynuacja dzieła Jezusa zostaje powierzona z jednej strony Duchowi Świętemu, a z drugiej - Apostołom $^{5}$. Zarówno Duch Święty jak i Apostołowie będą teraz świadczyć o Zmartwychwstałym (zob. Dz 15, 18 „Duch Święty i my”) przyczyniając się w ten sposób do rozwoju Kościoła, z tym jednak zastrzeżeniem, że priorytet należy do zbawczej mocy Ducha. On jest „Promotorem i absolutnym Panem przepowiadania”6. Głoszenie Ewangelii jest dziełem Ducha za pośrednictwem ludzkiego słowa. By było ono zawsze pełne Jego mocy, kontynuuje Hryniewicz, należy ciągle przyzywać Jego obecności. Wedle myśli lubelskiego dogmatyka, to nie Kościół rozporządza Ewangelią, ale to Ewangelia ma moc tworzenia Kościoła

\footnotetext{
Pascha II, s. 187.

Por. Pascha II, s. 188.

Por. Pascha II, s. 192.

Por. E. S. Siman, Le Promoteur et le Maître absolu de la Prédication, s. 203; cyt. za: Pascha II, s. 194.
} 
Teologia dogmatyczna

jako wspólnoty wciąż nawracających się ludzi. To Duch jest gwarantem, że głosząc i słuchając słowo Boże, chrześcijanin uczestniczy w zbawczym misterium Chrystusa. Dzięki Niemu Słowo jest żywe, bo trwa i działa we wspólnocie wierzących. Jest żywym słowem Jezusa, który we wspólnocie Kościoła wciąż wzywa do wiary i nawrócenia.

Dzięki temu, że słowo jest narzędziem oraz miejscem obecności Chrystusa i Jego Ducha, lubelski teolog nazywa Pismo Święte wraz z jego przepowiadaniem pewnego rodzaju „sakramentem” (por. KO 21), miejscem spotkania z ludźmi. „Słowo Boże zawiera pewne podobieństwo do sakramentu: jego forma zewnętrzna kryje w sobie misteryjną treść, która przenika do wnętrza ludzkiego dokonując w nim duchowej przemiany"7. Charakter sakramentalny słowa Bożego Hryniewicz wiąże z dwoma faktorami. Słowo Boże jest napełnione obecnością Tego, o którym daje świadectwo. Tak jak symbol, zawiera w sobie oznaczaną rzeczywistość, i dlatego może być nazywane „sakramentem słyszalnym"8. Równocześnie Pismo Święte pełni rolę performatywną: dzięki epiklezie urzeczywistnia to, co wyraża i dokonuje przemiany ludzkiego wnętrza. Stąd każde czytanie Pisma Świętego ma charakter liturgiczny.

Zdaniem lubelskiego teologa, głoszenie Słowa w formie świadectwa wyraźnie wskazuje na to, że Dobra Nowina jest nie tylko pamięcią tego, co się wydarzyło, ale jest przede wszystkim proklamacją aktualnej skuteczności wydarzeń paschalnych dla całego świata z równoczesną zapowiedzią ich spełnienia w eschatologicznej przyszłości ${ }^{9}$. Jest nadejściem tego, co ogłasza, „wyprzedzającą formą Paruzji”, „wewnętrzną transcendencją w stronę przyszłości Paschy całego świata"10. Podstawą aktualności objawienia misterium Chrystusa jest jednorazowe wydarzenie zmartwychwstania Ukrzyżowanego, które antycypuje cel całych dziejów. Dlatego wydarzenie paschalne jest, według lubelskiego

$7 \quad$ Pascha II, s. 194. Sakramentalną naturę tekstu biblijnego dobrze oddaje też Wilfred Cantwell Smith. Stwierdza, że Biblia ma charakter sakramentalny, ponieważ jej historyczna treść zawarta w księdze pełni funkcję mediacji w zaangażowaniu z czytelnikiem. W ten sposób tekst transcenduje swoją własną sytuację $\mathrm{w}$ momencie, gdy jest interpretowany przez daną wspólnotę. Por. W. C. Smith, What is Scripture? A Comparative Approach, Minneapolis 1993, s. 212-242.

Por. Pascha II, s. 204. Dokonując analogii pomiędzy naturą sowa i sakramentu, Hryniewicz w osobnym punkcie odnosi to do czynności sakramentalnej. Chodzi o to, że rozważa rolę słowa w połączeniu ze znakiem sakramentalnym. Celem jest ukazanie podobieństwa i współzależności między tymi dwoma środkami Zbawienia w ich strukturze i działaniu. Por. ibidem, s. 203-207.

Por. Pascha II, s. 191. 
teologa, częścią procesu przepowiadania, w którym Bóg, za pośrednictwem swych świadków, nadal daje świadectwo.

Jezus jest obecny nie tylko w słowie przepowiadania, ale także w tych, którzy je przepowiadają. Ta obecność sprawia, że słabe ludzkie słowo uzyskuje Bożą moc, pewność, której nie ma samo z siebie. W takim ujęciu, chodzi nie tylko o przekazywanie Dobrej Nowiny słowem, ale i całym życiem. Dlatego Hryniewicz stwierdza, że także apostolat staje się udziałem w paschalnej tajemnicy Chrystusa. Jest uczestnictwem zarówno w Jego Męce, jak i mocy Zmartwychwstania ${ }^{11}$. Według autora trylogii, te dwa wymiary Paschy są stale obecne w głoszonym słowie. Stąd misja Chrystusa w głoszeniu słowa Boga staje się zadaniem wspólnoty wierzących wobec świata. I tym samym jest udziałem w Jego mesjańskim - prorockim posłannictwie ${ }^{12}$. W ten też sposób Kościół, a w nim każdy człowiek bierze udział w Jego paschalnym misterium poprzez doświadczenie cierpienia i jednocześnie mocy Zmartwychwstania. Należy bowiem pamiętać, kontynuuje Hryniewicz, że głoszenie słowa Bożego nosi w sobie cząstkę cierpienia Chrystusa, a tym samym podobieństwo do Jego śmierci. Hryniewicz wyraża przekonanie, że głoszone w Kościele słowo Boże nosi w sobie samym znamię Paschy. Podziela kenotyczny stan krzyża: „nauka bowiem krzyża głupstwem jest dla tych, co idą na zatracenie" $(1 \text { Kor } 1,18)^{13}$. Wszystko to jednak zmierza nie do trwania w samym stanie niemocy,

11 D. Kurek-Chomycz, rozważając w swym artykule 2 Kor 4, 10 prezentuje apostolskie cierpienie jako udział w śmierci i życiu Jezusa oraz jako epifanię Bożej mocy. Stwierdza, że cała Pawłowa działalność apostolska, głównie jego cierpienie i nauczanie (lub raczej nauczanie w, i przez cierpienie) jest jego udziałem w śmierci Jezusa po to, by Jego zmartwychwstałe życie objawiło się w tych, którym je głosi. Kurek stwierdza, że Pawłowa interpretacja współcierpienia nie odnosi się w tym przypadku do całej chrześcijańskiej egzystencji, ale tylko Apostoła. Wielu egzegetów rozważając Pawłowe listy sugeruje pewien porządek hierarchiczny w uobecnieniu cierpień Jezusa, przypisując Apostołowi pierwszeństwo i rolę mediatora. Por. idem, „Always Carrying the Dying of Jesus In the Body" (2 Cor 4, 10). Apostolic Suffering as Participation In the Dying and the Life of Jesus, and as an Epiphany of God's Power, op. cit., s. 5-7. Zob także. C. B. Cousar, Theology of the Cross: The Death of Jesus in the Pauline Letters, Minneapolis, 1990, s. 149-157; F. J. Matera, Apostolic Suffering and Resurrection Faith. Distinguishing Between Appearance and Reality (2 Cor 4, 7-5.10), [w:] R. Bieringer, V. Koperski, B. Lataire (red.), Resurrection in the New Testament, Leuven 2002, s. 387-405.

Por. Pascha II, s. 196, 199.

Por. Pascha II, s. 196. 
ale do „postawienia ludzi w obliczu śmierci Chrystusa oraz mocy Jego zmartwychwstania"14. Hryniewicz pisze:

Kto głosi śmierć Pana (1 Kor 11, 26), ten włącza ludzi w obecność Chrystusa, który przeszedł przez śmierć. Słowo staje się w ten sposób obecnością. Stawia w obliczu Chrystusa ukrzyżowanego i zmartwychwstałego $(\ldots)^{15}$.

Jednocześnie, nie tylko ten, kto głosi, ale także ten kto przyjmuje słowo Boże przeżywa w sobie, zdaniem Hryniewicza, pewnego rodzaju „paschę", przejście ze śmierci do życia ${ }^{16}$. Głoszone bowiem słowo mocą Ducha wnika w głąb jestestwa człowieka i wzywając do wiary oraz nawrócenia, dokonuje w nim przemiany. Ujawnia się tu po raz kolejny dialektyka daru i zadania. Głoszone bowiem słowo, wyjaśnia autor rozważań paschalnych, zawsze pozostanie tylko (aż!) aktualnym wezwaniem, zaproszeniem Jezusa do udziału w Zbawieniu, które w sobie zawiera. Czyn jednak człowiek musi podjąć dobrowolnie, przez nawrócenie do życia w prawdziwej wolności. Tak oto ujawnia się podstawowy sens głoszenia Słowa: wzbudzić w człowieku wiarę i postawić go w obliczu misterium zbawczego Chrystusa. Słowo bowiem to nie tylko treść, ale jednocześnie zapowiedź i wezwanie do drogi, by tworzyć nowe wymiary życia. To eschatologiczny dar, który już uobecnia ukrytą przyszłość Paschy całego świata ${ }^{17}$.

\section{Uobecnienie $\mathbf{w}$ wierze}

W paschalnych rozważaniach Hryniewicza, wiara jest omawiana w kontekście słowa Bożego. W koncepcji lubelskiego ekumenisty chodzi o to, że Słowo wzbudza wiarę w człowieku i stawia w obliczu Ukrzyżowanego. Polega ona nie tylko na uznaniu słów za prawdziwe, ale na ich rzeczywistym przyjęciu w życiu, które wyraża się w życiu sakramentalnym i jego kontynuacji pośród codzienności. Dlatego też wiara jako uobecnienie misterium Chrystusa posiada podwójny wymiar: jest łaską Boga, który wzywa i jednocześnie czynem człowieka, który daje odpowiedź na Jego wezwanie zawarte w słowie ${ }^{18}$.

14

F. X. Durwell, La Résurrection de Jésus, mystère du salut, Le Puy 1950, s. 369; cyt. za: Pascha II, s. 197.

15 Pascha II, s. 196.

16

17

18

Por. Pascha II, s. 185.

Por. Pascha II, s. 202.

Por. Jan Paweł II, Wierzę w Boga Ojca Stworzyciela, Watykan 1987. Papież opisuje istotę i przymioty wiary. Rozwija integralną koncepcję wiary, podkreślając jej personalistyczny i dynamiczny charakter. Podkreśla, że wiara jest nade 
Wiara, przekonuje autor trylogii, jest warunkiem wejścia człowieka w misterium paschalne Chrystusa. Nie ma bowiem mowy o żadnym mechanizmie Zbawienia. Odkupienie należy do porządku łaski i miłości, a nie przymuszenia. Dlatego udział w nim zależy od dobrowolnej decyzji człowieka, która wyraża się właśnie w akcie wiary. Zdaniem Hryniewicza, „wiara jest osobowym aktem zespolenia człowieka z Chrystusem zmartwychwstałym, całościowym aktem zaufania i zgody na uczestnictwo w Jego tajemnicy"19. Wiara sama w sobie jest nie tylko otwarciem na misterium, ale już uczestnictwem w nim, ponieważ uwierzyć to jednocześnie przyjąć misterium.

Sam akt wiary ma, zdaniem lubelskiego teologa, charakter ofiary i uczestnictwa w niej. Jest bowiem obumarciem samemu sobie, wyrzeczeniem się autonomii własnego myślenia, rezygnacją z własnej logiki, uznaniem swojej słabości i ograniczoności oraz przeniesieniem ośrodka swego życia z siebie samego na Boga, jest posłuszeństwem wobec $\mathrm{Niego}^{20}$. Nie chodzi tu znów o samo trwanie w dolorystycznie rozumianej ofierze, ale w ofierze, która ma charakter paschalny, tzn. że poprzez udział w niej człowiek doznaje jednocześnie chwały Zmartwychwstania Chrystusa, która nadaje tej pierwszej radosny i pogodny charakter.

Według autora rozważań paschalnych, nie da się w ogóle pojmować wiary w oderwaniu od misterium paschalnego. Nie tylko dlatego, że wiara jest na nie ukierunkowana, czy też dlatego, że jej treścią jest nic innego jak zbawcze działanie Boga, które w misterium paschalnym osiągnęło szczyt. „Z istoty swej wiara jest rzeczywistością paschalną. W niej misterium paschalne znajduje swoje przedłużenie i dopełnienie, przez nią rozszerza zakres swojego zbawczego promieniowania i wchodzi w żywą relację z intymnym wnętrzem każdej osoby ludzkiej" ${ }^{21}$.

Przez wiarę człowiek może doświadczyć rzeczywistości, która zawiera ukryty sens, należy do rzeczywistości niewidzialnego świata. Wiara, oświecona mocą Ducha, daje w niej udział, bo Chrystus rzeczywiście, tzn. cieleśnie zmartwychwstał. Jego słowo, które pociąga ludzi do wiary i uwrażliwia na potrzeby drugiego człowieka nie jest zatem wyrazem jedynie moralnej zachęty i sentymentalnego aktu ze strony człowieka. Jest realnym wszczepieniem w Zmartwychwstałego. Nie

wszystko darem Boga, propozycją Zbawienia, oczekującą odpowiedzi i jako taka jest wolnym aktem ludzkim wyrażającym się w całożyciowej jego postawie. Por. ibidem, s. 21-62.

19 Pascha II, s. 197.

$20 \quad$ Por. Pascha II, s. 197.

$21 \quad$ Pascha II, s. 197. 
Teologia dogmatyczna

można zapomnieć, przypomina Hryniewicz, że „w Kościele wiara nie jest czymś zgoła subiektywnym, lecz rzeczywistością transsubiektywną i ponadindywidualną. Za jej pośrednictwem Duch Święty objawia nam misterium Chrystusa i odsłania pełny sens zmartwychwstania"22. On sprawia, że w wierze i przez wiarę misterium paschalne staje się rzeczywiście obecne i dostępne dla człowieka. Wiara „czerpie swą moc twórczą i przemieniającą z samego wydarzenia paschalnego, które przez Ducha Świętego działa ustawicznie na każdego wierzącego, i w tym sensie uobecnia się w jego życiu" ${ }^{23}$. Jej wyrazem i umocnieniem jest całe sakramentalne życie Kościoła.

\section{Uobecnienie sakramentalne}

Hryniewicz wyraża przekonanie, że współczesnym ludziom niełatwo przychodzi wierzyć w rzeczywistość, która ma strukturę misterium. Stwierdza, że wierzący o wiele chętniej oddają się działaniu ku potrzebom świata, co w pewnym sensie przyczynia się do upadku liturgii lub przynajmniej usunięcia jej z centrum życia chrześcijańskiego. Rwąca się więź między ministerium i misterium, jest, jego zdaniem, spowodowana utratą poczucia tajemnicy lub lęku przed nią. Dlatego lubelski teolog stara się przedstawić misterium wiary nie jako doktrynę, ale wszechogarniającą rzeczywistość życia wiary, która realizuje się w kulcie Kościoła. Analizuje nie tylko naturę sakramentu, ale także jego cel oraz sposób uobecnienia. Czerpiąc $\mathrm{w}$ dużej mierze z dorobku takich myślicieli jak Odo Casel czy Edward Schillebeeckx, stara się przedstawić przede wszystkim mistagogiczny charakter ekonomii sakramentalnej i ukazać jej zbawczą aktualność dla każdego człowieka. Poszukując istoty chrześcijaństwa, podobnie jak teologowie, na których się powołuje, zwraca uwagę na zbawczą, osobową relację Boga do człowieka.

22 W. Hryniewicz, Chrystus nasza Pascha. Zarys chrześcijańskiej teologii paschalnej, t. 1, Lublin 1982, s. 257, dalej: Pascha I. Hryniewicz niewiele miejsca poświęca na omówienie wiary. W innym dziele, Pedagogia nadziei. Medytacje o Bogu, Kościele i ekumenii, Warszawa 1997, nadmienia krótko, że wiara daje dostęp do zbawczej tajemnicy Chrystusa, a Duch Święty ustawicznie uzdalnia ludzi do przyjęcia jej daru. Por. ibidem, s. 18.

23 Pascha I, s. 210. Hryniewicz przypomina, że takie ujęcie nie narusza w niczym jednorazowego i niepowtarzalnego charakteru dzieła dokonanego przez Chrystusa. W innym miejscu teolog wyraża przekonanie, że w samym akcie wiary należy widzieć obecność Ducha Świętego. „Boży dar wiary daje uczestnictwo w zbawczej tajemnicy Chrystusa, a dokonuje się to dzięki działaniu Ducha Świętego". Idem, Sakrament Paschy i Pięćdziesiątnicy. Tajemnica Eucharystii $w$ świetle dialogu katolicko-prawosławnego, L. Górka, W. Hryniewicz (red.), Warszawa 1987, s. 31. 
Autor rozważań paschalnych wielokrotnie podkreśla, że całe życie chrześcijańskie to współdokonywanie misterium paschalnego z Chrystusem $^{24}$. Uważa, że konkretne chrześcijaństwo urzeczywistnia się przez osobową wspólnotę losu ze Zmartwychwstałym, która dokonuje się zwłaszcza w sakramentach. „Po cóż to sakramentalne przedłużenie?" - pyta za Schillebeeckxem i od razu przytacza jego odpowiedź: „Bez niego bowiem jedna z dogłębnie ludzkich cech Wcielenia się Boga byłaby dla nas stracona" 25 .

Hryniewicz przypomina, że Kościół stanowi rzeczywistość teandryczną, że jest wspólnotą zbawczą, ale istniejącą w czasie, w ziemskiej strukturze i dlatego domaga się pośrednictwa znaków sakramentalnych, które uobecniają dokonane raz na zawsze Zbawienie i czynią je dostępnym dla każdego człowieka. Po swym Zmartwychwstaniu, Chrystus przyjął pneumatyczny sposób istnienia, który sprawia, że jest obecny w inny sposób niż dotąd - ponadhistoryczny. Lubelski teolog wyjaśnia, że

gdyby Chrystus nie uczynił swojej niebiańskiej cielesności w jakiś sposób dla nas na ziemi widzialną, Jego Odkupienie nie byłoby dla nas, nie byłoby zwrócone ku nam. Pośrednictwo Chrystusa jako człowieka stałoby się wówczas bez znaczenia. Nie byłoby żadnej racji istnienia człowieczeństwa Chrystusowego po dokonaniu Odkupienia ${ }^{26}$.

Dlatego sakramenty są tym właśnie ziemskim przedłużeniem zbawczej roli chwalebnego człowieczeństwa Chrystusowego. Kościół otrzymał od Niego te środki zbawcze, by przedłużać Jego obecność. W tym tkwi, zdaniem Hryniewicza, istotny sens sakramentalnego uobecnienia, że skutecznie dają Kościołowi, a w nim człowiekowi każdego czasu, uczestnictwo w dokonanej raz na zawsze tajemnicy paschalnej. Dzięki temu sakramenty dokonują przemiany całego życia, aby stało się Paschą, czyli przejściem ku Bogu. W ten sposób uobecnienie prowadzi do uczestnictwa, dzięki któremu człowiek dostępuje łaski przebóstwienia i zbawienia.

Sakramenty w Hryniewiczowej koncepcji, to przede wszystkim dar i zaproszenie Boga. Jest to zaproszenie skierowane imiennie do każdego człowieka w określonym momencie jego życia do wspólnoty ze swym Stwórcą. Lubelski teolog odchodzi od scholastycznej terminologii, która pojmowała sakramenty w kategoriach reistycznych. Jego zdaniem, sakrament to przede wszystkim sam Chrystus, ponieważ

$24 \quad$ Por. Pascha II, s. 232.

25 Pascha II, s. 272.

26 E. Schillebeeckx, Chrystus, sakrament spotkania z Bogiem, tłum. A. Zuberbier, Kraków 1966, s. 66, cyt. za: Pascha II, s. 228. 
Teologia dogmatyczna

w Nim dokonało się doskonałe zjednoczenie Boga z człowiekiem. Jako znak obecności Boga, sam Chrystus, Jego osoba, wydarzenia z życia, uwielbione człowieczeństwo jest możliwością i miejscem spotkania z Bogiem. W tym właśnie sensie Chrystus stanowi pierwotny sakrament, czy też prasakrament ${ }^{27}$. Co więcej, Hryniewicz idzie dalej w swych rozważaniach, aniżeli inni teologowie. Uprawiając konsekwentnie teologię ekumeniczną, uzupełnia koncepcję chrystologiczną o trynitarną. Jego zdaniem, misterium, bo taka jest etymologia sakramentu $^{28}$, to sam Chrystus, Jego zbawcze, paschalne dzieło, ale jednocześnie i nierozerwalnie, rzeczywistość pneumatologiczna, eklezjalna i eschatologiczna.

Hryniewicz uświadamia, że różne momenty historii zbawienia nie przeczą sobie, ale stanowią w gruncie rzeczy jedną rzeczywistość. Jedno misterium objawia się w posłaniu przez Ojca Syna i Ducha, co jest kontynuowane w Kościele aż po eschatyczne spełnienie. Dlatego mówiąc o sakramentach, należy mieć na uwadze przede wszystkim samo misterium zbawcze Trójjedynego Boga, które uobecnia się w Kościele mocą Ducha. Stąd uprawnione jest stwierdzenie, że Kościól, jako historyczna konkretyzacja Chrystusa, stanowi niejako sakrament, czyli znak i narzędzie wewnętrznego zjednoczenia z Bogiem (por. KK 1, KL 26, 41 ${ }^{29}$. Poszczególne sakramenty stanowią konkretyzację sakramentalności Kościoła jako znaku bliskości Boga.

W tak szerokim kontekście rozumienia sakramentu, Hryniewicz za Caselem mocno podkreśla, że poszczególnych sakramentów nie można rozumieć jako środków łaski umożliwiających moralne oddziaływanie przeszłych aktów zbawczych ${ }^{30}$. Dar Zbawienia, którego Chrystus dokonał na krzyżu ma powszechne znaczenie, więc musi być obecny dla każdego człowieka i przezwyciężyć odstęp czasu oddzielający go od zbawczych wydarzeń ${ }^{31}$. Dlatego Hryniewicz uważa, wciąż inspirując się wyżej wspomnianymi teologami, że sakramenty nie są środkiem,

27 Por. Pascha II, s. 215.

28 Hryniewicz przypomina, że w Piśmie Świętym na próżno szukać słowa „sakrament”. Wyłoniło się ono ewolucyjnie z pojęcia misterium, które ma mocne biblijne zakorzenienie. Por. Pascha I, s. 52-54.

Por. Pascha, s. 215. Celem uporządkowania terminologii, Chrystusa określa się najczęściej jako prasakrament, Kościół zaś jako podstawowy sakrament, korzeń poszczególnych sakramentów, które konkretyzują sakramentalność samego Kościoła. Por. ibidem. Zob. S. C. Napiórkowski, Z Chrystusem $w$ znakach. Skrypt z sakramentologii ogólnej, Lublin 1984, s. 52-58. Zob. także. Y. Congar, Kościót jako sakrament zbawienia, tłum. T. Mazuś, Warszawa 1980. Por. Pascha II, s. 238. 
ale miejscem, przestrzenią spotkania z Bogiem; ich oddziaływanie nie jest moralne, ale ontologiczne; nie są to przeszłe akty, ale obecne.

Wyjaśniając powyższe stwierdzenie, Hryniewicz powołuje się na Caselowską, realistyczną teologię symbolu. Jego zdaniem dokonania benedyktyna z Maria Lach są bez precedensu, mimo że wielu teologów zgłaszało swe zastrzeżenia ${ }^{32}$. Hryniewicz jednak przyjmuje jego główne poglądy stając się kontynuatorem teologii misteryjnej. Uważa ją za nowy sposób myślenia w rozumieniu sakramentów, który skupia się na prawdziwym problemie. Koncepcję Casela - reasumuje Hryniewicz - Ratzinger ocenił jako „być może najbardziej owocną ideę teologiczną naszego stulecia" ${ }^{33}$.

Jej główną cechą jest pokreślenie, że w znaku sakramentalnym uobecnia się nie tylko duchowy skutek, ale cały czyn zbawczy Odkupiciela. Hryniewicz przytacza argumentację benedyktyńskiego mnicha, który stwierdza, że skutków nie można pojąć bez uobecnianej przez nie rzeczywistości. Zbawienie bowiem można osiągnąć nie drogą aplikacji, lecz mistyczno-realnego współżycia i współumierania z Chrystusem, a to z kolei wymaga, by zbawcze czyny Chrystusa były aktualnie obecne w sakramentach ${ }^{34}$.

W jego ujęciu znak sakramentalny to realny symbol, który zawiera oznaczaną rzeczywistośćc ${ }^{35}$. Innymi słowy, realno-symboliczne uobecnienie zbawczego czynu Chrystusa. Nie tworzy się nowy, ani nie powtarza się, ale uobecnia się raz dokonany czyn zbawczy. Hryniewicz przytacza argumentację Casela, który odwołuje się do analogii z dogmatem trynitarnym:

Hryniewicz sam przytacza zarzuty stawiane wobec Casela. Por. Pascha II, s. 240-250.

J. Ratzinger, Die sakramentale Begründung christlicher Existenz, 4. Ausg. Meitingen 1973, s. 5; cyt. za: Pascha II, s. 250.

Por. Pascha II, s. 235.

Por. Pascha II, s. 238. W teologii zachodniej duży wkład w rozumienie sakramentu, oraz całej rzeczywistości zbawczej, jako symbolu wniósł Louis-Marie Chauvet przez krytykę ontoteologicznych presupozycji klasycznej sakramentologii. Podobnie jak Hryniewicz, zdecydowanie odrzuca scholastyczny język przedstawiający sakrament w kategoriach rzeczy, którą można niejako „wyprodukować". Ukazuje specyfikę ich działania jako symbolicznej wymiany: jest darem - łaską, który wyraża samą osobę i dlatego wzajemną postawą powinna być wdzięczność, wyrażającą się w tym, że otrzymany dar przekazuje się innym. Chauvet porównując sakramenty do manny na pustyni pisze, że sakramenty nie są „,czymś”, tzn., nie są rzeczą posiadającą materialną wartość - są możliwe do spożycia tylko w momencie ich otrzymania. Zob. idem, Symbol and Sacrament. A Sacramental Reinterpretation of Christian Existence, trans. S. Madigan, M. Beaumont, Minnesota 1995, s. 99-135. 
Teologia dogmatyczna
Jak w Synu jest Ojciec, jak w Chrystusie jest Syn Boży, i przez to nie powstają dwaj Bogowie, tak również w sakramencie zawiera się i uobecnia zbawczy czyn Chrystusa, i przez to nie tworzy się nowy zbawczy czyn „sakramentalny” obok pierwotnego czynu zbawczego ${ }^{36}$.

Sakrament według Casela - kontynuuje lubelski teolog - to czynność kultyczna, za pośrednictwem której uobecnia się zbawcze misterium w sposób symboliczny i dramatyczny. Przez symbol rozumie nie tylko element materialny, ale także czynność sakramentalną jako „dramat”, w którym każdy może wziąć udział i stać się jego aktywnym współuczestnikiem, ponieważ w nim uobecnia się zbawcze misterium ${ }^{37}$. Hryniewicz zauważa, że Casel niechętnie posługiwał się sformułowaniem „uobecnienie”, ponieważ łatwo kojarzy się z uobecnieniem subiektywno-myślowym lub robi wrażenie podwojenia czynu zbawczego. Benedyktowi zaś chodzi o całkowitą tożsamość niepowtarzalnego czynu historycznego i jego sakramentalnej celebracji ${ }^{38}$. Dlatego można u niego znaleźć inne kategorie, takie jak naśladowanie. Czynność sakramentalna, wyjaśnia Hryniewicz, to symboliczne naśladowanie czynu Chrystusa, który jest w nim obecny. Należy jednak być ostrożnym używając także tej kategorii, ponieważ i ona łatwo kojarzy się $\mathrm{z}$ uobecnieniem wewnętrznym, mistyczno-moralnym. Krytycy teologii misteryjnej Casela wysuwali takie właśnie zastrzeżenia ${ }^{39}$. Tymczasem Casel, jak stwierdza Hryniewicz, mocno przeciwstawiał się pojęciu sakramentalnego „naśladowania” w sensie czysto moralnym, tzn. zjednoczenia duszy z Chrystusem. Podkreślał znacznie głębszy realizm ontyczny tego naśladowania, które obejmuje całe jestestwo człowieka. „Nie jest to bynajmniej «naśladowanie» zewnętrzne. Uobecnienie misterium «w sakramencie» jest równocześnie jego obecnością w człowieku" ${ }^{40}$. Lubelski teolog wyjaśnia nieco dalej:

w symbolicznej czynności sakramentalnej urzeczywistnia się w szczególny sposób wspólnota życia i losu z Chrystusem, nadając tym samym całemu życiu chrześcijańskiemu wyraźny rys chrystologiczny

$36 \quad$ O. Casel; cyt. za: Pascha II, s. 238.

Por. Pascha II, s. 239.

Według lubelskiego teologa, benedyktyński mnich nawiązuje w swej interpretacji do platońsko-patrystycznej idei obrazu i uczestnictwa. W takim ujęciu, zbawczy czyn pełni rolę pierwowzoru, sakramenty zaś są jego odzwierciedleniem i obrazem. Poprzez uczestniczenie w sakramentach człowiek uczestniczy w rzeczywistości pierwowzoru. Por. Pascha II, s. 239.

Por. Pascha II, s. 241-250.

Pascha II, s. 242. 
i eschatologiczny. Sakramentalny kult i praktyka życia przynależą wzajemnie do siebie w równym stopniu jak sakrament i naśladowanie Chrystusa ${ }^{41}$.

Przy okazji omówienia jednego z zarzutów, tzn. przeciwstawienia uobecnienia w duszy i uobecnienia w sakramencie, należy przywołać rozróżnienie, jakie poczynił Hryniewicz u początków swych paschalnych rozważań, a którego nie znajdzie się w drugim, centralnym tomie trylogii. Chodzi mianowicie o rozróżnienie, które kulowski teolog analizuje omawiając uobecnienie się „starej” Paschy w życiu Izraela $^{42}$. Jego zdaniem, uobecnienie wydarzenia paschalnego dokonuje się w podwójny sposób: 1) na płaszczyźnie psychologicznej, jako uobecnienie subiektywne ze strony człowieka, tj. przez wiarę, nadzieję i miłość; oraz 2) jako uobecnienie obiektywne ze strony Boga, który swą skuteczną interwencją zbawczą przeszłość czyni teraźniejszością.

Jahwe aktualizuje i uobecnia zbawienie paschalne; daje w nim uczestnictwo wszystkim, którzy „wspominają” Jego czyny. Oznacza to, że między teraźniejszością a przeszłością przerzucony został tajemniczy pomost, który przezwycięża dzielącą je odległość ${ }^{43}$.

Dzięki liturgicznej celebracji święta, działanie Boga w przeszłości i antycypacja eschatologicznej przyszłości, staje się teraźniejszością. Przy tym, stwierdza Hryniewicz, anamneza Paschy w celebracji, oznacza coś więcej niż czysto psychologiczny akt pamięci ze strony człowieka. Jego

41 Pascha II, s. 244. W innym miejscu lubelski teolog stwierdza, że „celebracja sakramentalna dokonuje się w przestrzeni życiowej tworzonej przez Ducha Świętego". Pascha II, s. 236. Hryniewicz do tego stopnia podkreśla związek znaku sakramentalnego z życiem, że nadaje temu drugiemu charakter sakramentalny. Por. Pascha II, s. 340. Uważa, że sakramentów nie można rozumieć punktualistycznie, lecz jako proces, który obejmuje całe życie i poprzez nie się weryfikuje. Przez chrzest, który zapoczątkowuje życie sakramentalne, każdy człowiek staje się bytem paschalnym. Ponadto, celem sakramentów w jego przekonaniu jest przemiana życia, aby stało się Paschą - przejściem ku Bogu. Por. Pascha II, s. 285.

Por. Pascha II, s. 42-50.

43 Pascha I, s. 47. Papież Pius XII w swej encyklice Mediator Dei pisze także o dwóch rodzajach uobecnienia. Pierwsza, to bytowa łączność z Chrystusem przez sakrament chrztu i Eucharystii, druga zaś to łączność moralna, która wyraża się, jego zdaniem, przez odczucie tego, co czuł Chrystus, gdy składał swa ofiarę. W obu przypadkach papieżowi chodzi o to, by wierni podczas Eucharystii włączali samych siebie w ofiarę Chrystusa. Używa słowa conditio victimae (współofiarowanie), by wyrazić istotę tej ofiary. Także w innych miejscach encykliki, papież bardzo często akcentuje potrzebę uczestnictwa wiernych w składaniu ofiary eucharystycznej. Zob. Pius XII, Encyklika „Mediator Dei et Hominum", Castel Gandolfo 1947, zwłaszcza nr 60-61. 
Teologia dogmatyczna

zdaniem jest kultycznym uobecnieniem historycznego wydarzenia. „Nie jest jedynie subiektywnym wspomnieniem zbawczych wydarzeń, mieszczącym się w ramach przeżycia religijnego. Jest misterium kultycznym, czyli uobecnieniem tego, co Bóg uczynił dla zbawienia ludzkości" ${ }^{44}$.

Jak w izraelskiej teologii święta akcent spoczywa na liturgicznym dzisiaj, tak samo Casel, a wraz z nim Hryniewicz nawiązuje do idei „wiecznego dzisiaj” Boga. Chcąc uzasadnić fakt uobecniania się zbawczego czynu w znaku sakramentalnym, Hryniewicz przytacza koncepcję Casela, którą nieco dalej sam bardzo obszernie rozwija. Chodzi o odwołanie się do idei wieczności Boga, który nie jest ograniczony czasem i przestrzenią oraz funkcji Ducha Świętego, który znosi przedziały czasowe i daje uczestnictwo w wieczności samego Stwórcy.

Przed podjęciem próby omówienia sposobu uobecnienia Hryniewicz przypomina, by nie chcieć rozumieć wszystkiego. Misterium pozostanie tajemnicą. Dodaje jednak, że mimo apofatyczności, należy podejmować starania w celu przybliżenia zrozumienia prawd przekraczających ludzką percepcję. Jego zdaniem, Sobór uniknął tej próby i nie wyjaśnił sposobu uobecnienia. Nie powiedział nawet jednoznacznie, co się uobecnia podczas sprawowania sakramentu, wyjaśnia teolog. W konstytucji liturgicznej jest jedynie mowa o tym, że Kościół obchodząc misteria odkupienia otwiera „bogactwa dzieł i zasług swojego Pana, aby w jakiś sposób uobecniały się w każdym czasie, a wierni mogli zetknąć się z nimi i dostąpić łaski zbawienia" (KL 102).

Idea wieczności Boga i funkcji Ducha, którą Hryniewicz podejmuje wyraźnie za Caselem, próbuje wyjaśnić sposób uobecnienia się misterium w znaku sakramentalnym. Jego zdaniem, Pascha i zesłanie Ducha Świętego to „wiecznotrwałe tajemnice”" ${ }^{45}$, które posiadają charakter jednocześnie czasowy i ponadczasowy. Dokonały się w określonym momencie historii „raz na zawsze”. Zdaniem Hryniewicza, realizm wcielenia, czyli osobowego wejścia Syna Bożego w rzeczywistość czasu i przestrzeni, domaga się i potwierdza rzeczywistą relację do czasu i historii. Dlatego stwierdza, że raz dokonane wydarzenie nie może się dokonać jako takie w czasie teraźniejszym. Równocześnie, wydarzenie to nie przeminęło wraz z czasem. Jako dzieło Syna Bożego, dopełnione w Zmartwychwstaniu i Zesłaniu Ducha, zawiera w sobie wartość transcendentną, która sprawia, że dzieło zbawcze pozostaje nieprzemijające i wiecznotrwałe. Hryniewicz przybliża rozumienie wiecznotrwałości Paschy i zesłania Ducha w różny sposób.

$44 \quad$ Pascha I, s. 162.

45 Por. E. Schillebeeckx, Chrystus..., dz. cyt, s. 84; cyt. za: Pascha II, s. 259. 
Odwołując się do perspektywy antropologicznej uzasadnia, że choć człowiek, istota żyjąca w czasie i przestrzeni, podejmuje akty, które przemijają, jednak ich duchowo-osobowa wartość pozostaje. To, co się dokonało wczoraj, wyciska jakieś piętno na dzisiaj człowieka, dlatego nie przemija to, czego człowiek doświadczył. Analogicznie, duchowa treść życia Jezusa - miłość i posłuszeństwo - pozostaje w Nim, nawet po śmierci, w Jego nowym sposobie bytowania. Tak właśnie duchowa i osobowa treść wydarzeń zbawczych uobecnia się, według autora trylogii paschalnej, w celebracji sakramentalnej, choć same wydarzenia w wymiarze fizycznym należą do przeszłości.

Zdaniem lubelskiego teologa, perspektywa antropologiczna w pewnym stopniu przybliża zrozumienie tajemnicy wiecznotrwałości, ale jest to raczej obecność duchowej treści, a nie trwałości i aktualności samych wydarzeń. Dlatego Hryniewicz powołuje się na rolę teandryzmu Wcielenia. Stwierdza, że czyny Jezusa są jednocześnie czynami Chrystusa, Syna Bożego, więc mają one udział w wieczności Boga. Jako takie posiadają w sobie coś więcej niż zwyczajne ludzkie dzieła, które przemijają z czasem, a pozostawiają tylko skutki. Jako czyny Boga, są wiecznie aktualne. Hryniewicz powołuje się też na E. Schillebeeckxa, który stwierdza, że „ludzkie czyny Jezusa są osobowo czynami Boga, są przeniknięte Boskim sposobem istnienia i obecności" ". Dlatego odkupieńczy czyn pozostaje nadal aktualny w czasie. Jest obecny w sakramencie, ponieważ jego historyczny czyn zawiera element wiecznotrwały ${ }^{47}$.

Hryniewicz rozpatruje także tajemnicę czasu i wieczności, by przybliżyć rozumienie wiecznego charakteru Paschy. Uważa, że między nimi istnieją wzajemne relacje, mimo zasadniczych różnic. Charakteryzują się bowiem dwoma różnymi sposobami istnienia. Pierwsze jest ograniczone, bo podlega przemijaniu, drugie jest od tego wolne. Jednak mimo tej różnicy, lubelski teolog podkreśla, że wieczność nie wyklucza czasu, a czas może uczestniczyć w wieczności. Ponadczasowe akty zbawcze (kairos) dokonują się w czasie (chronos), ale ich wymiar czasowy zostaje przezwyciężony przez zetknięcie się $\mathrm{z}$ wiecznością Boga, która wynosi czas do wieczności. Dlatego misterium paschalne jest rzeczywistością, w której styka się czas i wieczność. Jego rolą, zdaniem Hryniewicza, jest przekształcenie czasu od wewnątrz, tzn.

\footnotetext{
$46 \quad$ Ibidem, s. 88; cyt. za: Pascha II, s. 262.

$47 \quad H r y n i e w i c z$ stwierdza, że Schillebeeckx nie wyjaśnia wyraźnie na czym polega ów element ponadhistoryczny. Stwierdza, że wiecznotrwałość dotyczy strony zarówno duchowej jak i cielesnej aktu zbawczego i jako taki jest nadal obecny w sakramentach. Por. Pascha II, s. 263.
} 
przeobrażenie tego, co czasowe w to, co wieczne. Lubelski teolog przytacza stwierdzenie V. Wanacha, według którego

zadaniem sakramentów jest nie tyle uobecniać misterium zbawcze, ile raczej nas samych wyzwolić spod panowania czasu, abyśmy mogli wejść w kontakt z ponadczasowym aktem Paschy Chrystusa i osiągnąć rzeczywistą wspólnotę z Chrystusem ukrzyżowanym i zmartwychwstałym ${ }^{48}$.

Zatem podstawą ponadczasowości jest działanie Boga, dzięki któremu Odkupienie jest wciąż obecne w każdym momencie istnienia człowieka w postaci sakramentalnej.

Hryniewicz rozpatruje wreszcie ponadczasowość w świetle wewnętrznej jedności dzieła Chrystusa. Poszczególne wydarzenia z życia Jezusa, jak pisze lubelski teolog, stanowią w gruncie rzeczy jedno wielkie misterium, które w swej treści zbawczej jest niezależne od upływu czasu. Wcielenie, uzasadnia, dokonało się w czasie, ale trwa nadal jako akt i wydarzenie, ponieważ Chrystus wciąż aktualizuje raz przyjęte człowieczeństwo ${ }^{49}$. Gdyby nie ta ustawiczna aktualizacja, Chrystus przestałby być człowiekiem. Także ludzka śmierć Chrystus jako początek wieczności posiada charakter ponadczasowy. Hryniewicz wyjaśnia, że ukrzyżowanie jako zjawiskowa oprawa śmierci Jezusa należy do przeszłości, ale jej wewnętrzna istota, tj. ostateczna decyzja miłości i posłuszeństwa, oddania się Ojcu zostaje uwieczniona. Trwa na zawsze zarówno akt oddania, jak i jego przyjęcia ze strony Ojca, który został potwierdzony w Zmartwychwstaniu. Hryniewicz dodaje, że ponadczasowość śmierci i jednocześnie uwielbienia Jezusa jest wyraźnie widoczna w jej sakramentalnej antycypacji podczas Ostatniej Wieczerzy. To w niej jest obecne wydarzenie, które historycznie nastąpi następnego dnia. Fakt ten potwierdza, że wydarzenia te mają wartość transcendentną w stosunku do czasu. Zatem tak, jak zbawcze wydarzenie zostało antycypowane, tak samo może być uobecniane w późniejszym czasie, zachowując tę samą zbawczą treść: ,jako osobowy czyn Syna Bożego, oddanie to trwa dalej w wiecznej aktualności, a nie tylko w swoich skutkach" ${ }^{50}$. Dlatego właśnie, reasumuje Hryniewicz, wydarzenie paschalne, mimo swej relacji do historii, pozostaje aktualne w Chrystusie i dzięki temu może się wciąż uobecniać w sakramentach, choć już bez zewnętrznych elementów. Teolog rozważań paschalnych niezachwianie podkreśla, że czyn zbawczy nie trwa jedynie na sposób

48 Pascha II, s. 269. Por. V. Wanach, Agape. Die Liebe als Grundmotiv der neutestamentlichen Theologie, Düsseldorf 1951, s. 389-391.

Por. Pascha II, s. 270. 
ponadczasowej idei lub też tylko w swej treści etycznej jako normatywny przykład postępowania, ani też tylko nie jest obecny w swoich skutkach jako „,skarbiec zasług”51. Jest wciąż obecne jako wydarzenie w swej ontycznej treści.

Ostatecznie wiecznotrwałe misterium paschalne jest obecne w sakramencie za pośrednictwem uwielbionego człowieczeństwa Chrystusa i mocy Ducha. Uczestnictwo w akcie Odkupienia, podkreśla Hryniewicz, jest nieodłączne od zjednoczenia z Chrystusem zmartwychwstałym w mocy Ducha. Czerpiąc z rozważań lubelskiego dogmatyka z zakresu implikacji Zmartwychwstania Chrystusa, można stwierdzić, że to właśnie dzięki uwielbieniu Chrystusa wydarzenie Paschy stało się wiecznotrwałe. Pascha obejmuje i przenika wszystkie czasy. Wydarzenie Zmartwychwstania wymyka się kategoriom czasu i przestrzeni, dzięki czemu umożliwia, by podczas celebracji sakramentu, zwłaszcza Eucharystii, każdy człowiek miał możliwość udziału w zbawczych tajemnicach Jezusa Chrystusa. Teolog dodaje, że udział człowieka $\mathrm{w}$ śmierci nie polega na dezintegracji i zniszczeniu, ale jest przejściem do uwielbienia wraz z Chrystusem. Jest zaproszeniem do odnalezienia prawdziwego sensu życia, do wspólnoty ze swym Stwórcą.

Uobecnienie zbawczych tajemnic w sakramencie dokonuje się zawsze mocą Ducha, którego Hryniewicz nazywa twórcą porządku sakramentalnej, duchowej i obiektywnej obecności zmartwychwstałego Chrystusa $^{52}$. Po swym Zmartwychwstaniu, sam Chrystus prosi Ojca o zesłanie Ducha Świętego (zob. J 14,16), co zdaniem Hryniewicza świadczy najdobitniej o nieprzemijającej aktualności wydarzeń zbawczych. To Duch sprawia nowy, sakramentalny sposób obecności Zbawienia i jest przyczyną jego skuteczności. Sakramenty są wciąż jednym i tym samym kultem, prośbą (epiklezą) składaną przez samego Chrystusa do Ojca o zesłanie Ducha na wspólnotę ${ }^{53}$. Dzięki tej trynitarnej skuteczności, w Kościele w sakramentalny sposób urzeczywistnia się misterium paschalne. Jest to czyn niezależny od świętości człowieka, choć jako osobowy dar odnosi najpełniejszy skutek, gdy zostaje przyjęty i staje się jego udziałem. Hryniewicz kolejny raz podkreśla, że nie chodzi jedynie o stosunek moralnego podobieństwa, ale uczestnictwo w samych aktach zbawczych.

\footnotetext{
51 Por. ibidem.

52 Por. Pascha II, s. 415.

$53 \quad$ Por. W. Hryniewicz, Duch Święty, sakramenty, człowiek. Ku spotkaniu tradycji chrześcijaństwa Wschodu i Zachodu, „Znak” 32(1980) s. 1211. Por. także sens epiklezy eucharystycznej w: W. Hryniewicz, Sakrament Paschy i Pięćdziesiątnicy, op. cit., s. 40-45.
} 
Teologia dogmatyczna

Wyjaśniając bliżej rolę Ducha w sakramentalnym uobecnieniu zbawczych tajemnic, Hryniewicz stwierdza, że Jego osobowe działanie jest z natury swej transcendentne. Swój historyczny kształt uzyskuje jedynie w dziejach Chrystusa, Kościoła i poszczególnych ludzi ${ }^{54}$. To On wynosi misterium paschalne Chrystusa ponad historię, w sferę wiecznie trwającego „teraz” i jednocześnie „wciela je rzeczywiście w ludzkie dzieje i urzeczywistnia w tajemnicy ludzkiej wolności"55. Czyny Chrystusa dosięgają człowieka każdego czasu, ponieważ dzięki zbawczej mocy Ducha, akty dokonane w człowieczeństwie Chrystusa stają się z kolei aktami wspólnoty Kościoła, a w niej każdego z wierzących.

On jest „Duchem wiecznym” (por. Hbr 9, 14), obecnym w mesjańskiej funkcji Jezusa ziemskiego, która przedłuża się w Kościele. Tak jak był obecny w ofierze krzyża, tak samo daje współudział w niej każdemu człowiekowi podczas sakramentalnego uobecnienia. Nawiązując do znanej formuły H. Mühlena, Hryniewicz powiada, że Duch jest ,jedną Osobą w wielu osobach", tzn. tą samą w Chrystusie i w wielu osobach ludzkich ${ }^{56}$. Jego trwanie przenika wszystkie czasy i miejsca, dlatego Pascha, dokonana raz na zawsze, nie może być powtarzana, ale ma charakter nieprzemijający, który sięga w najdalszą przyszłość. Dzięki Duchowi jest uobecniania i dostępna dla wszystkich pokoleń ludzkich.

Lubelski teolog wprowadza do swych wyjaśnień pojęcie inkluzji pneumatologicznej, która dopełnia aspektem pneumatologicznym patrystyczną ideę przyjęcia całej ludzkości w człowieczeństwie Jezusa podczas Wcielenia, chociaż akcent spoczywa na ofierze krzyża. Hryniewicz dochodzi do wniosku, że

współudział Ducha w Odkupieniu jest istotnym czynnikiem zrozumienia obecności wszystkich ludzi w człowieczeństwie Chrystusa na krzyżu. On włącza ich w tajemnice Odkupienia. Dzięki Duchowi Świętemu cała ludzkość mająca uczestniczyć w odkupieniu jest już obecna w paschalnej ofierze Jezusa. Udział Ducha w tej ofierze stanowi antycypację

54 Por. PaschaII, s. 276; M. Kowalczyk, Duch Święty wżyciu idziałaniu Ludu Bó̇ego, [w:] Duch Odnowiciel, L. Balter [i in.] (red.), Kolekcja Communio, t. 12, Poznań 1998, s. 183-217.

Pascha II, s. 277.

56 Por. Pascha II, s. 279. Zob. A. Czaja Una Mystica Persona. Zasadnicze elementy pneumatologicznej eklezjologii Heriberta Mühlena, CT 63(1993) fasc. 4, s. 82; Idem, Jedna Osoba w wielu osobach, op. cit., s. 99n. Tę specyfikę działania Ducha Mühlen wyraża także w kategoriach przyczynowości. Hryniewicz zapożycza ją od niemieckiego dogmatyka, by wyjaśnić zbawcze działanie Chrystusa. W tym miejscu, teolog z Padebornu stosuje ją do wyjaśnienia osobowego działania Ducha, który zamieszkując we wnętrzu ludzkiej osoby udoskonala ją i prowadzi do głębszego zjednoczenia tworząc jedną mistyczną osobę w wielu osobach. Por. ibidem. 
Jego obecności i działania w tych, którzy przez wieki będą uczestnikami daru odkupienia. Jest to ten sam Duch - w Chrystusie i w wielości osób ludzkich. Chodzi tu jednak nie tyle o ontyczne włączenie wszystkich ludzi (inkluzja ontologiczna) w zbawcze działanie Jezusa, ile raczej o wszczepienie wynikające z osobowej właściwości Ducha Świętego (inkluzja pneumatologiczna). Właściwością tą jest jednoczenie osób. (...) Jako „Duch wieczny”, współdziałający w paschalnej ofierze Chrystusa, On także zawiera w sobie - w sposób Jemu tylko właściwy - wszystkich tych, którzy uczestniczyć będą w tej ofierze, uobecniającej się Jego mocą na przestrzeni dziejów. Obecność Ducha w zbawczych czynach Chrystusa umożliwia ustawiczne trwanie tajemnicy odkupienia w Kościele ${ }^{57}$.

\section{Uobecnienie egzystencjalne}

Lubelski dogmatyk wykazuje w swoich rozważaniach, że misterium paschalne, które urzeczywistnia się zwłaszcza za pośrednictwem poszczególnych sakramentów, odnawia i uświęca ludzkie życie w różnych jego sytuacjach ${ }^{58}$. W jego integralnie rozumianej koncepcji sakramentu, o której także była już mowa, chodzi o to, że sakramentów nie można rozumieć punktualistycznie, jako jednorazowego momentu, niejako religijnego interwału, całkowicie oderwanego od codziennego życia. Są one rzeczywistością, która swe wypełnienie znajduje pośród codzienności, w podstawowej aktywności właściwej każdemu człowiekowi. Życie jest ich wypełnieniem, stanowi odpowiedź człowieka, który przez swój świadomy wysiłek stale uczestniczy w misterium Chrystusa, a przez to staje się także jego własnym misterium, będąc jego „współdokonywaniem”.

W ten sposób lubelski teolog po raz kolejny daje wyraz swemu szerokiemu rozumieniu sakramentu, które obejmuje, jego zdaniem, nie tylko siedem sakramentów świętych (w sensie ścisłym), ale także wszelkie czynności święte i całe życie ${ }^{59}$. Uważa, że ekonomia sakramentalna nie dotyczy jedynie określonej liczby siedmiu sakramentów, ale

57 Pascha II, s. 282-283. Ponieważ nie sposób omówić uobecnienia zbawczych tajemnic bez odwołania się do roli Ducha, dlatego zostało tu wyjaśnione pojęcie inkluzji pneumatologicznej, które dopełnia pojęcie solidarnego zespolenia z Chrystusem, które było przedmiotem rozważań pierwszego rozdziału. Por. Pascha II, s. 339.

59 Por. PaschaII, s. 357-360. Hryniewiczinspirując się tu głównie teologią wschodnią wymienia spośród takich czynności: poświęcenie wody, krzyżma, świątyni czy też ikony w tradycji wschodniej. Wyjaśnia, że rolę poświęceń i benedykcji w aktualizacji misterium paschalnego podkreśla także tradycja Kościoła katolickiego, ale nie przypisuje im jednak charakteru ściśle sakramentalnego. Por. ibidem. W innym kontekście, podkreślając ścisły związek duchowości sakramentalnej z codzienną egzystencją, lubelski teolog nazywa życie swoistym sakramentem 
Teologia dogmatyczna oznacza raczej pewien sposób zbawczego działania Boga w świecie, który można by nazwać mianem sakramentalizmu. Jest to zatem pewna stała reguła, którą odsłaniają dzieje zbawienia. Wyraża się ona w tym, iż rzeczywistość widzialna staje się manifestacją jeszcze większej rzeczywistości zbawczej ${ }^{60}$.

Lubelski dogmatyk odwołuje się do charakterystycznej mu argumentacji chrystologiczno-pneumatologicznej w uzasadnieniu swoich poglądów. Uważa, że to poszerzenie sytuacji sakramentalnej ma swoje uzasadnienie w Chrystusie jako podstawowym sakramencie zbawienia. Hryniewicz wyjaśnia, że sakrament to osoba Chrystusa, Jego zbawcze misterium, które dzięki powszechnej mocy Zmartwychwstania obejmuje wszystkie momenty historii zbawienia. W ten sposób, misterium Chrystusa jako podstawowy sakrament znajduje swą kontynuację w czasie Kościoła aż po eschatyczne spełnienie. Wszystko to dokonuje się moca Ducha, który czyniąc Kościół rzeczywistością sakramentalną sprawia także, że wszystko, co jest w Jego mocy może stać się rzeczywistością sakramentalną, czyli pośredniczącą w spotkaniu z Bogiem oraz miejscem zbawienia człowieka. Chodzi tu więc nie tylko o siedem sakramentów, ale także wszelkie święte czynności i całe życie człowieka z jego podstawową aktywnością, które uobecnia i aktualizuje misterium paschalne.

Na tę powszechność działania Boga wskazuje - jego zdaniem - właśnie symbol „siedmiu sakramentów” "61. Uważa, że nie chodzi o dokładność liczby siedem, ale o to, że misterium paschalne ogarnia całość ludzkiej egzystencji, we wszystkich jej wymiarach.

Całe życie chrześcijańskie ma charakter sakramentalny i symboliczny. W swojej całości staje się ono znakiem Bożego działania, miejscem obecności zbawczego misterium Paschy i Pięćdziesiątnicy. W sferę tego zbawczego działania włączone są rzeczy tego świata, stając się w ten sposób pośrednikiem łaski Ducha Świętego [... $]^{62}$.

Dlatego Hryniewicz uważa, że Zbawienie nie działa tylko w siedmiu sytuacjach, ale wszędzie tam, gdzie życie ludzkie jest odnawiane przez życie Boże. W ten sposób poszerza się sytuacja sakramentalna.

Jeżeli istnieje tylko jeden dar zbawienia, którego źródłem jest paschalne misterium śmierci i zmartwychwstania Chrystusa oraz zesłanie Ducha Świętego, wówczas wszystko może być sakramentem. Jeżeli istnieje

paschalnym. Por. idem, Chrześcijaństwo nadziei. Przyszłość wiary i duchowości chrześcijańskiej, Kraków 2002, s. 218.

60 Pascha II, s. 215.

61 Por. Pascha II, s. 334-340.

$62 \quad$ Pascha II, s. 339. 
w gruncie rzeczy tylko jeden sakrament podstawowy (to Mysterion), którym jest Chrystus, wówczas mocą Jego Ducha wszystko może stać się sakramentem - w całej różnorodności przejawów działania i sytuacji ludzkiego życia ${ }^{63}$.

Hryniewicz stwierdza przy tym, że taka sytuacja nie pomniejsza dogmatyczna znaczenia sakramentów.

Wręcz przeciwnie, horyzont zostaje poszerzony o nowe punkty widzenia w kierunku powszechności daru zbawienia i różnorodności dróg, na których staje się on udziałem człowieka ${ }^{64}$.

W ten sposób całe życie i każda wartość doczesna stanowiąc pośredniczącą rolę w spotkaniu z Bogiem, staje się paschalnym sakramentem zbawienia i dlatego także przez tę podstawową aktywność człowiek uczestniczy w misterium paschalnym Chrystusa.

\section{Zakończenie}

Dzięki Duchowi Świętemu misterium Paschy jest kontynuowane w przestrzeni chwalebnego Ciała Chrystusowego, którym jest Kościół. W ten sposób, ludzie wszystkich czasów mają możliwość udziału w misterium Chrystusa. Hryniewicz często podkreśla, że rzeczywistość ta nie dokonuje się automatycznie, lecz wymaga zajęcia aktywnej postawy ze strony człowieka, która realizuje się w żywym kontakcie ze Zbawicielem. Osobowe oddziaływanie Chrystusa uzdalnia człowieka do przemiany i aktywnego udziału w Jego życiu, pozostawiając człowiekowi niejako wolną przestrzeń do dopełnienia. Ma ono miejsce zwłaszcza podczas uobecnienia zbawczych tajemnic Chrystusa. Misteryjna i realna obecność Chrystusa w słowie Bożym, wierze, sakramentach oraz ludzkiej egzystencji umożliwia zjednoczenie z Chrystusem poprzez wspólnotę losu. Dlatego karmienie się słowem Bożym, sakramentami i tworzenie prawdziwie ludzkiej, paschalnej egzystencji staje się formą udziału w misterium Chrystusa.

Słowa klucze: misterium paschalne, uobecnienie zbawczych tajemnic, słowo Boże, wiara, sakramenty, doczesna aktywność.

\section{Bibliografia:}

1. Bieringer R., The Authority of the Bible for Theology, „Bulletin ET. Zeitschrift für Theologie in Europa“ 8(1997).

63 Pascha II, s. 340.

64 Ibidem, s. 340 . 
Teologia dogmatyczna

2. Chauvet L.-M., Symbol and Sacrament. A Sacramental Reinterpretation of Christian Existence, tłum. S. Madigan, M. Beaumont, Minnesota 1995.

3. Congar Y., Kościót jako sakrament zbawienia, tłum. T. Mazuś, Warszawa 1980.

4. Cousar C. B., Theology of the Cross: The Death of Jesus in the Pauline Letters, Minneapolis, 1990.

5. Czaja A., Jedna Osoba w wielu osobach. Pneumatologiczna eklezjologia Heriberta Mühlena, Opole 1997.

6. Czaja A., Una Mystica Persona. Zasadnicze elementy pneumatologicznej eklezjologii Heriberta Mühlena, CT 63(1993) fasc. 4, s. 79-95.

7. Durwell F. X., La Résurrection de Jésus, mystère du salut, Le Puy 1950.

8. Hryniewicz W., Chrystus nasza Pascha. Zarys chrześcijańskiej teologii paschalnej, t. 1, Lublin 1982.

9. Hryniewicz W., Chrześcijaństwo nadziei. Przyszłość wiary i duchowości chrześcijańskiej, Kraków 2002.

10. Hryniewicz W., Duch Święty, sakramenty, człowiek. Ku spotkaniu tradycji chrześcijaństwa Wschodu i Zachodu, „Znak” 32(1980).

11. Hryniewicz W., Nasza Pascha z Chrystusem. Zarys chrześcijańskiej teologii paschalnej, t. 2, Lublin 1987.

12. Hryniewicz W., Pedagogia nadziei. Medytacje o Bogu, Kościele i ekumenii, Warszawa 1997.

13. Hryniewicz W., Sakrament Paschy i Pięćdziesiątnicy. Tajemnica Eucharystii $w$ świetle dialogu katolicko-prawostwnego, L. Górka, W. Hryniewicz (red.), Warszawa 1987.

14. Jan Paweł II, Wierzę w Boga Ojca Stworzyciela, Watykan 1987.

15. Kowalczyk M., Duch Święty w życiu i dziataniu Ludu Bożego, [w:] Duch Odnowiciel, L. Balter [i in.] (red.), Kolekcja Communio, t. 12, Poznań 1998, s. $183-217$.

16. Kurek-Chomycz D., „Always Carrying the Dying of Jesus In the Body” (2Cor 4,10). Apostolic Suffering as Participation In the Dying and the Life of Jesus, and as an Epiphany of God's Power, [w:] T. Merrigan, F. Glorieux (red.), „Godhead Here in Hiding”: Incarnation and the History of Human Suffering [w przyg. do druku].

17. Matera F. J., Apostolic Suffering and Resurrection Faith. Distinguishing Between Appearance and Reality (2 Cor 4,7-5. 10), [w:] R. Bieringer, V. Koperski, B. Lataire (red.), Resurrection in the New Testament, Leuven 2002.

18. Napiórkowski S. C., Z Chrystusem w znakach. Skrypt z sakramentologii ogólnej, Lublin 1984.

19. Pius XII, Encyklika „Mediator Dei et Hominum”, Castel Gandolfo 1947.

20. Ratzinger J., Die sakramentale Begründung christlicher Existenz, 4. Ausg. Meitingen 1973.

21. Schillebeeckx E., Chrystus, sakrament spotkania z Bogiem, tłum. A. Zuberbier, Kraków 1966.

22. Smith W. C., What is Scripture? A Comparative Approach, Minneapolis 1993.

23. Wanach V., Agape. Die Liebe als Grundmotiv der neutestamentlichen Theologie, Düsseldorf 1951. 